\title{
Subsistence marine fishing in a neoliberal city: a political ecology analysis of securitization and exclusion in Durban, South Africa
}

\author{
Marc Kalina ${ }^{1}$ \\ Alexio Mbereko \\ Brij Maharaj \\ Amanda Botes \\ Durban University of Technology, South Africa \\ The Women's University in Africa, Zimbabwe \\ University of KwaZulu-Natal, South Africa \\ Durban, South Africa
}

\begin{abstract}
In post-apartheid South Africa, the blue economy has been identified as an untapped resource for creating employment and stimulating economic growth. However, in the port city of Durban, subsistence fishing has formed an important component of both the livelihood and identity of individuals living in marginalized communities adjacent to the harbor for over a century. However, since America's 9/11 terrorist attacks a number of new international laws and regulations have shaped local legislation and policies which seek to exclude the public from accessing the harbor area. As a consequence, increased security measures have contributed to an increasingly closed off space, where increased barriers to access have effectively isolated the harbor from the surrounding city, and restricted entry to local fishers. As a result, fisherfolk have been forced to contest their exclusion from the harbor, risking expulsion or arrest to continue practicing their livelihoods. Utilizing a political ecology framework, and integrating perspectives drawn from over a decade of qualitative fieldwork, this article explores how securitization narratives operate as a tool for the neoliberal exclusion of the poor from public space. Analysis suggests that the securitization of Durban's harbor has served to bar entry to the poor towards participating in South Africa's blue economy, while allowing elites exclusive access to marine resources.

Key Words: Indian Ocean, securitization, blue economy, South Africa, subsistence fishing, neoliberalism, public space

Abstract

In post-apartheid South Africa, the blue economy has been identified as an untapped resource for creating employment and stimulating economic growth. However, in the port city of Durban, subsistence fishing has formed an important component of both the livelihood and identity of individuals living in marginalized communities adjacent to the harbor for over a century. However, since America's 9/11 terrorist attacks a number of new international laws and regulations have shaped local legislation and policies which seek to exclude the public from accessing the harbor area. As a consequence, increased security measures have contributed to an increasingly closed off space, where increased barriers to access have effectively isolated the harbor from the

\footnotetext{
${ }^{1}$ Dr. Marc Kalina, Post-Doctoral Research Fellow, Urban Futures Centre, Durban University of Technology, Steve Biko Campus, Durban, South Africa. Email: marc.kalina "at" gmail.com. Dr. Alexio Mbereko, Lecturer, Faculty of Social Sciences and Gender Transformative Sciences, The Women's University in Africa, 549 Arcturus Road, Manresa, Greendale, Zimbabwe. Email: ambereko "at" gmail.com. Prof. Brij Maharaj, School of Agricultural, Earth and Environmental Sciences, University of KwaZulu-Natal, Howard College Campus, 269 King George V Ave, Durban, South Africa. Email: maharajb "at" ukzn.ac.za. Amanda Botes, Sustainability Consultant, Durban, South Africa. Email: amandadray "at" gmail.com. Thank you to JPE editors and two referees. This is the second article in John Childs and Christina Hicks (eds.). 2019. "Political ecologies of the blue economy in Africa", Special Section of the Journal of Political Ecology 26: 323-465.
} 
surrounding city, and restricted entry to local fishers. As a result, fisherfolk have been forced to contest their exclusion from the harbor, risking expulsion or arrest to continue practicing their livelihoods. Utilizing a political ecology framework, and integrating perspectives drawn from over a decade of qualitative fieldwork, this article explores how securitization narratives operate as a tool for the neoliberal exclusion of the poor from public space. Analysis suggests that the securitization of Durban's harbor has served to bar entry to the poor towards participating in South Africa's blue economy, while allowing elites exclusive access to marine resources.

Key Words: Indian Ocean, securitization, blue economy, South Africa, subsistence fishing, neoliberalism, public space

\section{Resumen}

En Sudáfrica postapatheid, la economía azul ha sido identificada como un recurso desaprovechado por crear empleo y estimular el crecimiento económico. No obstante en la ciudad portuaria de Durban, la pesca de subsistencia ha sido un componente importante tanto de la forma de vida, como de la identidad de los individuos de comunidades marginadas que por un siglo, han vivido en las cercanías del puerto. Sin embargo, desde los ataques terroristas del 11 de septiembre de 2001 en Estados Unidos, nuevas leyes y regulaciones internacionales han determinado la legislación local para excluir al público del acceso al área del puerto. Como consecuencia, la intensificación de medidas de seguridad ha contribuido al aumento de espacios reservados, donde el refuerzo de las medidas de seguridad han aislado el puerto de la ciudad que lo rodea, y han restringido el paso a los pescadores locales. Como resultado, los pescadores se han visto forzados a disputar su exclusión del puerto, arriesgándose a ser arrestados o expulsados de la actividad que los sustenta. Con base en un marco de ecología política e integrando perspectivas de más de una década de trabajo cualitativo en campo, este artículo explora cómo las narrativas de titulización operan como una herramienta neoliberal para excluir a los pobres del espacio público. El análisis sugiere que la titulización del puerto de Durban ha servido para obstruir la participación de los pobres en la economía azul sudafricana, mientras permite a las élites un acceso exclusivo a los recursos marinos.

Palabras clave: Océano Índico, titulización, economía azul, Sudáfrica, pesca de subsistencia, neoliberalismo, espacio público

\section{Introduction}

Fishing is our right!

Stop harassing fishermen!

Why must poor fishermen suffer in a democratic South Africa?

Do not criminalize the poor!

Source: Protest placards (26/09/2007)

The slogans above, depicted on placards carried at a 2007 protest organized by subsistence fishers in Durban, South Africa, point to the daily struggle these individuals face in accessing the marine fisheries that support their livelihoods. A vibrant subsistence fishing community, predominantly descended from former servants and indentured laborers from India, has been living and working within Durban's harbor for generations (Dray 2009; Maharaj 2017). However, since the end of apartheid in 1994, the South African state has faced significant neoliberal pressure to remove barriers to international trade and encourage global capital markets, often at the expense of local employment (Bond and Desai 2011). As part of international regulations put into place since the September 11, 2001 terrorist attacks, the Transnet National Port Authority (TNPA), the parastatal organization that serves as 'landlord' for Durban's harbor, has had to come into compliance with the International Ship and Port Facility Security Code (ISPS), a United Nations international agreement signed by ports all over the world after the September 11, 2001 terrorist attacks, and designed to implement global standards for safety and security (Dray 2009; RSA 2005). Consequences for violating these agreements include punitive measures designed to negatively affect South African trade and bar access to American markets (De Boer and Madlala 2008). 
Consequently, the TNPA has assumed greater authority to control access to, and navigation within, the harbor, as well as approaches to the port, with the objective of bringing the port-area into international compliance and maintaining Durban's position as a 'world-class' port (Dray 2009; Meyer 2007). Finally, new port regulations issued in 2009 strengthened Transnet's grip over the harbor area, creating additional barriers and control points for access to port facilities and introducing a permit system designed to restrict public access to most areas of the harbor (RSA 2009). Due to the above agreements, Durban's harbor has become progressively enclosed over the past decade, with access to the water barred by countless fences, gates, and security checkpoints, and as a result, less and less space is available for public use. As the final slogan from the protest above indicates, this progressive securitization of the port has barred access for the poor to public spaces within the harbor, forcing fishers to break the law in order to access traditional fishing locations. Nonetheless, Durban's subsistence fishing community has contested this exclusion, and a decade of resistance has revealed conflict within the management of the harbor between international neoliberal influences and a South African developmental state that has identified equitable access to marine resources as a precursor to growing the blue economy, and is typically predisposed to be sympathetic to the land (and sea) use claims of its citizens.

Building on critical literature which characterizes securitization as a tool for the exclusion of the poor from urban public spaces and the informal economy (Becker and Müller 2013; Belina and Helms 2003; Bodnar 2015; Harvey 2000), this article draws upon extensive qualitative participatory fieldwork in order to examine how securitization operates in practice, through the everyday experiences of Durban's subsistence fishers. Its purpose is to demonstrate how securitization narratives have directly contributed to the neoliberal exclusion of the poor from public space, which, in the case of Durban's fishers, serves to bar the poor from participating in the blue economy.

Recent geographical and political ecology perspectives have pushed for a more reflexive and ontologically open conceptualization of the blue economy narrative (Childs and Hicks 2019; Foley 2017; Morrissey 2017; Winder and Le Heron 2017). We contribute to this theorization by utilizing a broad political ecology framework which interrogates the 'neoliberal assault' on urban public space, while accommodating for the diverse social, cultural, political, economic, and environmental factors affecting subsistence fisher's relationship with South Africa's blue economy (Attoh 2011; Harvey 2000, 2008; Iveson 2007; Leitner et al. 2007; Low and Smith 2006; Maharaj 2017). Our analysis draws specific attention to the impacts that securitization has had towards marginalizing subsistence fishers, as well as the coping strategies and contestations that they have had to devise in order to continue practicing their livelihoods. Finally, we argue that securitization of public space within Durban's harbor disproportionately impacts the poor, who are less able to adapt to new circumstances, access private land, or re-negotiate access to public fishing spots, limiting the ability of subsistence fishers to contribute to South Africa's blue economy.

\section{Securitization, public space, and the blue economy}

Securitization has been identified within political ecology and geographical literature as one of the ways in which the neoliberal state guarantees the "freedom" of the market "by law, authority, force, and, in extremis, by violence" (Harvey 2000: 179). "Conceived as the hegemony of security and (dis)order concerns regarding the "proper" use, design, and (re)ordering of urban space" securitization has been characterized by the creation and implementation of new legal instruments, enforced by re-envisioned policing tactics, social control strategies, and aggressive design (Becker and Müller 2013: 78). Interest in the increased control over public space can be interpreted as a manifestation of ongoing urbanization of neoliberalism and according to Mitchell and Beckett (2008). It reflects the increased interconnectedness of global capital, eager to manage risk for investors across markets. Indeed, competition defines this dynamic, as urban planners acknowledge that the perception of a space as a safe home for investment is an essential component for a city to compete on a global stage (Becker and Müller 2013; Belina and Helms 2003; MacLeod 2011; Smith 1996; Weber 2002).

The emergence of securitization as one of the principal tools available to the neoliberal city for controlling urban environments in the face of 'undesirable elements', such as the homeless or informal workers, has been well documented (Becker and Müller 2013; Belina and Helms 2003; Bodnar 2015; Peck 2004; Wacquant 2008). Evidence from African cities suggest that securitization can be interpreted as an extension of 
the on-going neoliberal privatization of public space which has often led to the marginalization of poor urban citizens (Bond and Desai 2011; Cornelissen 2011; Habib and Padayachee 2000). In Durban, authorities often embody Wacquant's (2008: 199) colorful description of securitization as "the cleansing of the built environment and the streets from the physical and human detritus wrought by economic deregulation and welfare retrenchment so as to make the city over into a pleasant site of and for bourgeois consumption", perpetuating violent confrontations with informal traders which are characterized by removal, disruption, and forced criminality (Cornelissen 2011; Hanseen and Vaa 2004; Skinner 2008). At the same time, private entities with the help of local governance structures encroach and securitize public spaces in urban areas for profit (Cornelissen 2011). Finally, across South Africa, private (and often illegal) enclosure of formerly public spaces have often been justified as a response to chronically high violent crime rates (Landman 2012; Soja 2000). As public spaces are replaced by private spaces and pseudo-public spaces, what results is increasing segregation and public space that is unsafe for all (Lemanski 2004). Driving this privatization is a fear of crime and a fear of 'the other', or a fear of difference, and therefore a conceptualization that public space must be ordered and planned has resulted (Caldeira 2000). However, there is growing evidence that these actions disrupt urban spaces and contribute to the widening gap between the poor and the rich (Bond and Desai 2011; Habib and Padayachee 2000; Landman 2006).

Like the majority of informal workers, subsistence fishers rely on the right to access public spaces like streets, harbors, piers, beaches, and city parks, however their struggles have been poorly documented (Low and Smith 2006). Bueger (2013) notes coastal states have reacted to the wave of insecurity which swept the post 9/11 world by looking to leverage effective maritime security regimes as a way to maximize contributions from the Blue Economy to economic development. These efforts favor international corporations who are party to neoliberal structures and agreements, at the expense of informal operators who are more difficult to regulate and control (Bueger 2013). In effect, the goal is to facilitate a 'safe space' for global trade and capital flows, despite the impacts this may have on the poor who have historically depended upon these resources. Such narratives can be seen to compromise the right to the city by all citizens, since under a neoliberal securitization regime the right to the city shifts to the hands of private and quasi-private interests (Harvey 2008). As a result of these neoliberal arrangements, Winder and Le Heron (2017: 20) argue that blue economy projects could justifiably be considered an extension of the 'new' extractivism into ocean and coastal zones.

\section{Conceptualizations of space and the blue economy}

As Morrissey (2017) describes, a growing awareness on the part of coastal and marine policy-makers of the need to understand and account for the economic and social impacts of marine activity has forced contemporary social scientists to reconceptualize their disciplines in order to accommodate the unique properties of our oceans and seas. Conversely, recent geographical and political ecology contributions have pushed for a more reflexive and ontologically open conceptualization of the blue economy narrative which moves beyond the economy and speaks to broader assemblages of actors, requirements, and circumstances (Foley 2017; Morrissey 2017; Urquhart and Acott 2012; Winder and Le Heron 2017).

In this vein, the struggles of Durban's subsistence fisher community to access public space and the blue economy has received a fair amount of scholarly attention over the past decade, including contributions by the authors of this article. For example, two unpublished theses by Dray (2009) (epse. Botes) and Van Grootheest (2011) both provide in-depth accounts of the methods by which subsistence and recreational fishers contested their exclusion from public piers on Durban's beachfronts during the 'neoliberal assault' on public space that occurred in the lead up to South Africa's hosting of the 2010 FIFA World Cup. Dray's (2009) contribution in particular, provides excellent detail on the impacts of exclusion for fishers, particularly the loss of livelihoods, heritage, and identity, and that material is partly incorporated into this article's narrative. Maharaj (2017) advances Dray's (2009) account by describing the various forms of public activism and engagement by which fishers were able to reclaim some of their lost space. Maharaj's (2017) article benefits from the author's deep connection with Durban's fishers' community, which lends his analysis rich detail and insight. Theoretically, these pieces are all grounded in traditional neoliberal narratives centered on the privatization of public space for the benefit of consumers and elites (Dray 2009; Maharaj 2017). Although they address exclusion and 
dislocation within Durban's harbor, their focus is largely on the privatization of Durban's beachfronts and they contextualize these contestations within other, wider protests on other issues such as service delivery. Furthermore, they do not adequately grapple with the securitization narrative driving exclusion within the harbor. Building on these earlier contributions, the purpose of this article is to unpack this securitization narrative, while connecting it to broader patterns of neoliberal exclusion from public space. Furthermore, it contributes to political ecology theorization on the blue economy as it interrogates the products of exclusion and the marginalization of poor fishers whose historical relationship with the marine environment has effectively been criminalized through international neoliberal influences (Poe et al.2015; Urquhart and Acott 2012; Veuthey and Gerber 2011).

\section{Method}

This article draws upon a deep body of empirical data built over the past decade through extensive qualitative research within south Durban's subsistence fishing community. Fieldwork has consisted of formal interviews with stakeholders from the municipality and the port, semi-structured interviews with members of the subsistence fisher community, observations of fishers conducted during numerous site visits, as well as observing meetings and protests planned by the KwaZulu-Natal Subsistence Fisherfolks Forum (KZNSFF). Furthermore, some key respondents have been interviewed at multiple points since 2006, allowing for narratives to evolve and develop as events in the harbor have unfolded.

Altogether, this article draws on over 40 qualitative semi-structured interviews in addition to extensive participatory observation. This occurred across two main periods of data collection, 2006-2009 and 2016-2018, bridged by continuous engagement with members of the KZNSFF. The approach was both constructivist and interpretivist, allowing for the co-construction of knowledge between subject and researcher (Mottier 2005). Participants were purposively sampled with the assistance of KZNSFF, as well as through the researchers' past relationships within the fishing community. Due to the sensitive nature of the topic, as well as the often-illegal actions subsistence fishers take to practice their livelihoods, the confidentiality of participants is absolute, and respondents will be referred to here by pseudonyms. The exception are key stakeholders within the public realm, who have agreed to their names appearing within this article. Finally, in regards to dates, unfortunately, memory is perishable, and often different respondents would cite different dates for specific incidents. When possible, we have turned to documentary evidence in order to help support a coherent and definitive timeline of events. However, where such evidence is not available, we have evaluated conflicting accounts and made every effort to be as accurate and specific as possible.

\section{Durban as a port city: history and context}

Located on the shores of the Indian Ocean, along South Africa's east coast, the city of Durban is first and foremost a port city. Never a capitol or administrative center, the city (politically consolidated since 2000 into eThekwini Municipality) has traditionally depended upon its broad harbor and associated industries for its economic development (Freund and Padayachee 2002). Once resembling what Jones (2002: 102) vividly describes as, "many of the other picturesque but ultimately irrelevant tidal lagoons that proliferate on the KwaZulu-Natal coast", Durban's harbor has been drastically transformed over the 150 years of the city's history. Its mouth has become fixed and cemented, sheltered by long piers jutting into the sea, while its floor has been dredged (a constant necessity due to the multitude of rivers feeding the harbor) to greater and greater depths to accommodate each generation of mega-ship. However, the harbor remains a varied space. Its northern edge is dominated by a long sea wall, creating a promenade for residents of the CBD, as well as restaurants, private marinas and yacht clubs for the wealthy (see Figure 1). The west and south-west are industrial, home to numerous shipping berths, warehouses, and the second biggest container port on the African continent (Freund and Padayachee 2002). While the south and the south-east, in the backwaters of the port, the harbor still resembles the former tidal lagoon, which until around the turn of last century, had a larger population of hippopotamus (Hippopotamus amphibius) than ships (Freedman 2013). Here, dense stands of endangered mangrove trees cut a swathe through their industrial surroundings and shelter a sensitive habitat and breeding grounds for a multitude of fish species (Freedman 2013). 


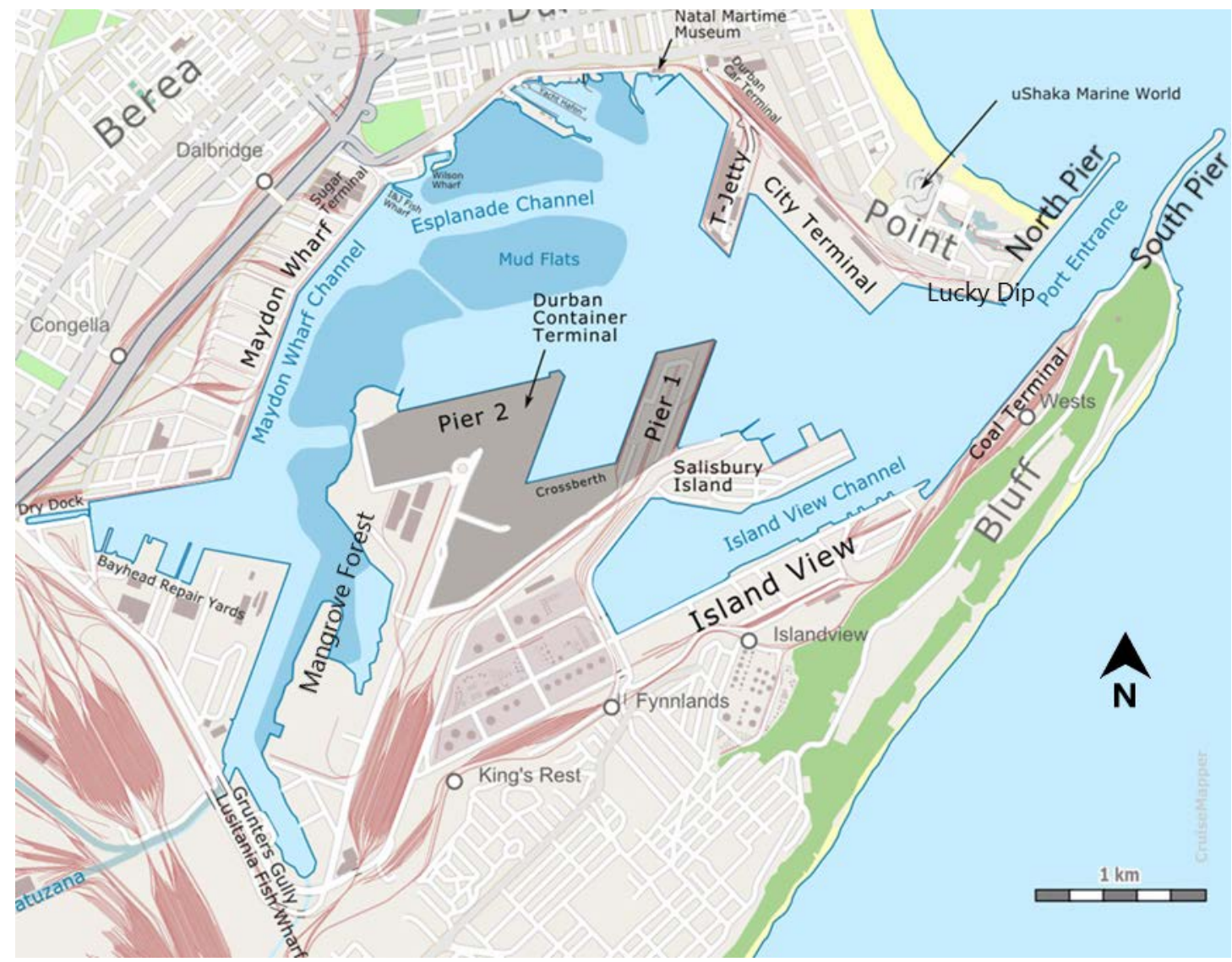

Figure 1: Map of Durban's harbor (CruiseMapper 2018).

Despite contemporary concerns over its decline (see Bond 2019), the strategic importance of Durban's harbor to the South African economy cannot be over emphasized as it handles the overwhelming majority of the nation's container traffic (Steinberg 2005). The busiest port in Sub-Saharan Africa, it is the main general cargo port for the country, and its container terminal is the fourth largest in the southern hemisphere, handling 31.4 million tons of cargo per year (Baillache 2017; Dray 2009). Sixty four percent of all goods imported into South Africa enter through Durban's harbor, while a number of specialized facilities, like the massive sugar terminals which dominate Maydon Wharf (see Figure 1), point to the role of the port as the main window to the world for South Africa's exports (Baillache 2017). The port also contains terminals for handling bulk commodities and automobiles, while housing a South African naval base, a petro-chemical offshore terminus, extensive dry docks and repair facilities, as well as a terminal for cruise ships (Meyer 2007). Locally, the port is one of the principal sources of employment in Durban. Although specific employment numbers are difficult to pin down across such a diverse range of economic activities, one rough estimate puts port-ancillary employment at around 50,000, while Transnet employs another 53,000 directly, a total that constitutes nearly $10 \%$ of the municipality's total workforce (Dyer 2014). However, as Steinberg (2005) has emphasized, the port of Durban is also a contraband hub, with significant quantities of illegal or counterfeit goods entering the harbor every day. This includes a large quantity of narcotics, being imported for local consumption and exported to foreign markets. 


\section{0 years of fishing heritage}

The communities that exist at the south end of the harbor, beyond the mangroves and across the rail yards and shipping depots of the container terminal, in an area known as the south Durban industrial basin, have relied on a connection to the sea for employment and subsistence for generations. Predominantly of Indian descent, many of these individuals can trace their history back to indentured laborers that first arrived from India in 1860 (Dray 2009). These original indentured laborers signed contracts for a period of five years to work at a fixed wage on the sugar plantations that were proliferating in what was then the British colony of Natal (Marie 1986). Many laborers stayed in the Point area of the harbor and were employed by South African Railways, the harbor, and shipping companies. They stayed in "barracks" which were overcrowded and cramped with very little privacy. After the period of indenture was over, many of the Indians went into hawking, market gardening and fishing to earn a living (Marie 1986).

One particular community of former indentured laborers established itself on Salisbury Island, a small spit of land in the harbor that has long since been consumed by the modern container terminal. Relying on fishing skills brought with them from India, these early fishers used seine nets, a type of fishing net which is weighted at the bottom so that it hangs vertically in the water allowing the ends to be drawn in to trap fish (Pillay 2002). Locally known as "seine netters", these early communities relied on fishing for profit and subsistence. (Pillay 2002). These fishers also practiced line fishing, and by 1870 the first rowing boats were being employed to go out to sea (Pillay 2002; Scott 1994). After an outbreak of plague in 1900 the Salisbury Island community was moved to Fynnlands (see Figure 1), a neighborhood on the Bluff that was leased from the South African Railways (Scott 1994). With easy access to the harbor, Fynnlands also became a thriving fishing village and the residents fished daily as a means to earn a living (Pillay 2002). Over the years the Fynnlands community, in addition to the remaining Indian communities on the Point and other areas surrounding the harbor, prospered, eventually establishing control over the entire fresh fish market in Durban (Pillay 2002; Scott 1994). In 2007 some fishers were still able to recall childhoods spent living in the fishing 'village' of Fynnlands or in Clairwood. Speaking while fishing at South Pier, one fisher recollected this proximity and freedom of access: "[I] used to live in Clairwood. That was like my backyard...the harbor. You could walk out of your house and walk into the bay..." (Ismail 19/06/2007). One 77 year old man who was formerly a resident in the Bayhead area remembered the Fynnlands area clearly as he visited friends who lived there in the 1940s (Samuel 18/09/2007). The houses that the fishermen lived in at Fynnlands were "on stilts" due to the high waters from the bay and he saw them "catching fish from the doorway." He differentiated between the fishers at Fynnlands and those at Bayhead through the use of their fishing equipment. The fishers at Fynnlands had their own rowing boats whilst the people at Bayhead predominantly used netting sacks to catch fish (Samuel 18/09/2007).

Following the Second World War, the city of Durban, and the harbor area in particular, experienced a period of rapid industrial development. As the port facilities expanded, the Fynnlands community was forced to give way as their homes were demolished for oil storage facilities (Scott and Criticos 1988). Most moved to new homes in adjacent communities to the south-west, neighborhoods like Clairwood, Bayhead, Wentworth or Merebank. The 1950 Group Areas Act saw further dislocation as many Indian families, including those from other parts of the city, were forcibly moved to the Indian 'township' Chatsworth, located further south of the harbor (Pillay 2002; Scott and Criticos 1988). These communities, collectively a part of the aforementioned south Durban industrial basin maintain a predominantly Indian or multi-racial character to this day, however multiple dislocations have broken apart traditional fishing communities and diluted them with new residents from other, non-fishing, backgrounds. Furthermore, new communities, located further from the harbor, were no longer able to maintain their strong reliance on its resources for their livelihoods or subsistence. As a consequence, the fishing tradition within the south Durban Indian community has slowly decreased, as new generations have shifted to other forms of labor, or, since the end of apartheid in 1994, moved within the city or country to find work (Mara 1986; Scott and Criticos 1988). The environmental degradation of the harbor area has been an additional factor in this shift as water pollution, over-fishing, the extension of the South Pier, and sand pumping for the beaches have all contributed to lower catch numbers and smaller fish (Scott and Criticos 1988). As of 2009 only ten 'seine netter' families remained in the trade, with just one old wooden 
traditional boat in use amongst them (Dray 2009). Despite these dislocations, fishing, and their foundational relationship with the harbor, remains central to the history and identity of many Indian families in south Durban.

\section{Fish and livelihoods}

Under South African law, a subsistence fisher is classified as any person who regularly catches fish for personal consumption or for the consumption of their dependents, and may still engage in the local sale or barter of excess catch (RSA 1998). During the apartheid era the commercial fishing industry was controlled by and for white South Africans who had the resources to go out to sea, whilst non-white subsistence fishers, employing either net or pole and line, were restricted to the shore (Dray 2009). Access to public space was strictly restricted along racial lines, with the best fishing spots reserved for the white minority. Evidence of this system can still be seen today on older piers where faded painted numbers show how spaces were numbered and allocated for white and non-white fishers. This racial exclusion is partly responsible for the popularity of the harbor as a fishing spot as it was generally accessible to non-white communities in the south Durban industrial basin and was largely free of racial restrictions. Within these communities, fishing, both in the harbor and on the beachfront, continues to be an important source of subsistence and recreation, and there remains an estimated 15,000 subsistence fishers within the municipality (Dray 2009).

Maharaj (2017) provides a detailed typology of the variety of fishers that frequent Durban's harbor. He describes a spectrum of fishers ranging from the 'oldies' who largely depend on fishing for their livelihood, to the 'manne' and 'respectables' who work other jobs but identify as fishers, and often rely on fishing for recreation, extra income, or "something extra for the pot" (Maharaj 2017: 749; Mohammed 04/05/2018). Amongst the 'oldies' fishing is a part of their "everyday lifestyle" (Morgan, 19/05/2007). Most of the fishers interviewed described a routine of fishing every day and often every night, or as one 'oldie' on South Pier described, "I come in the daytime and if I don't catch during the day I come back at night" (Keshav, 19/05/2007). Of their catch, these 'oldies' often sell the majority, particularly the higher value fish like Keelback Salmon, Kingfish, or Yellowtail, while taking the rest home to their families. As one fisher stated "I take for selling and we eat a lot of fish... we eat fish three times a week...we eat fish curry, fish and chips, fish breyani..." (Morgan, 19/05/2007). Another fisher emphasized how much his family had depended on his ability to fish; "I've raised my family on fishing" (Keshav, 09/05/2007). A fisher who 'pumps' cracker shrimp from the sand to sell as bait stated that he had supported his two children at school, and a new-born baby, through the money he made from selling the bait to other fishers. Referring to his baby, he stated "I buy him everything he needs from crackers money" (John, 05/04/2007). Finally, for many fishers, including the 'manne' and 'respectables' who do not rely on fishing for their livelihoods, fishing provides a form of social safety net, with fishers able to fall back on fishing during hard times or unemployment (Maharaj 2017; Mohammed, 04/05/2018).

\section{'The poor man's boat': fishing Durban's harbor}

Prior to the second World War, the harbor remained predominantly open, with fishers able to fish "all round" and cast a line in any spot of deep water (Abdul, 05/05/2018). However, the progressive industrialization of the area has closed many formerly important fishing spots, leaving only a few as viable. These spots are North Pier and South Pier which collectively form the harbor mouth, the sand banks near the Esplanade, and Grunter Gully, located in the backwaters of the port. At present, the yields from the harbor are not nearly high enough to support a commercial industry, yet these spots continue to sustain a vibrant and historic subsistence and recreational fishing culture, and remain the principal points of contestation between fishers and port officials.

The North Pier, originally named Milne's Pier, was built in 1894 whilst the 500m long South Pier was constructed in 1893 (Mara 1986). Extending out along each side of the harbor mouth (see Figure 2), these two structures are ideal for fishing. South Pier, located in closer proximity to the south Durban neighborhoods (see Figure 1), has solidified itself as the premier spot for pole and line fishing from shore. Mohammed (04/05/2018), an elderly fisher originally from the Point area but now residing in Chatsworth, describes South Pier as one of the finest fishing grounds in South Africa. Extending far out to sea, it provides access to deeper water than is normally accessibly from shore, yielding a wide array of fish: 
We used to catch anything from Barracuda, Keelback Salmon, Kingfish, sharks, practically any fish. We would even catch a deep-sea fish called Dorado....... These are fish you would normally need a boat to catch. This is why we used to call South Pier the 'Poor Man's Boat'. The variety of fish we used to catch there is unreal. (Mohammed, 04/05/2018)

However, as the next section describes, starting in 2005 both piers underwent substantial renovations, with North Pier being moved 100 meters to the north in addition to a number of structural changes to both piers. Prior to these renovations South Pier was the most desirable fishing location in the harbor as it was easier to cast a line into deeper water because the main shipping channel passed closed to the Pier (Ahamed, 05/05/2018; D'Sa, 07/05/2018; Mohammed, 04/05/2018). However, the renovations, including the addition of concrete dolosse (reinforced concrete blocks) to the structure have made South Pier more difficult to traverse, while the widening of the harbor mouth has shifted the channel closer to North Pier, which has since become the more desirable fishing spot (Abdul 05/05/2018). The clearing near the base of North Pier, known as 'Lucky Dip', is particularly popular as it provides access to the deep water of the channel while also offering picnic spaces and parking (Mohammed 04/05/2018).

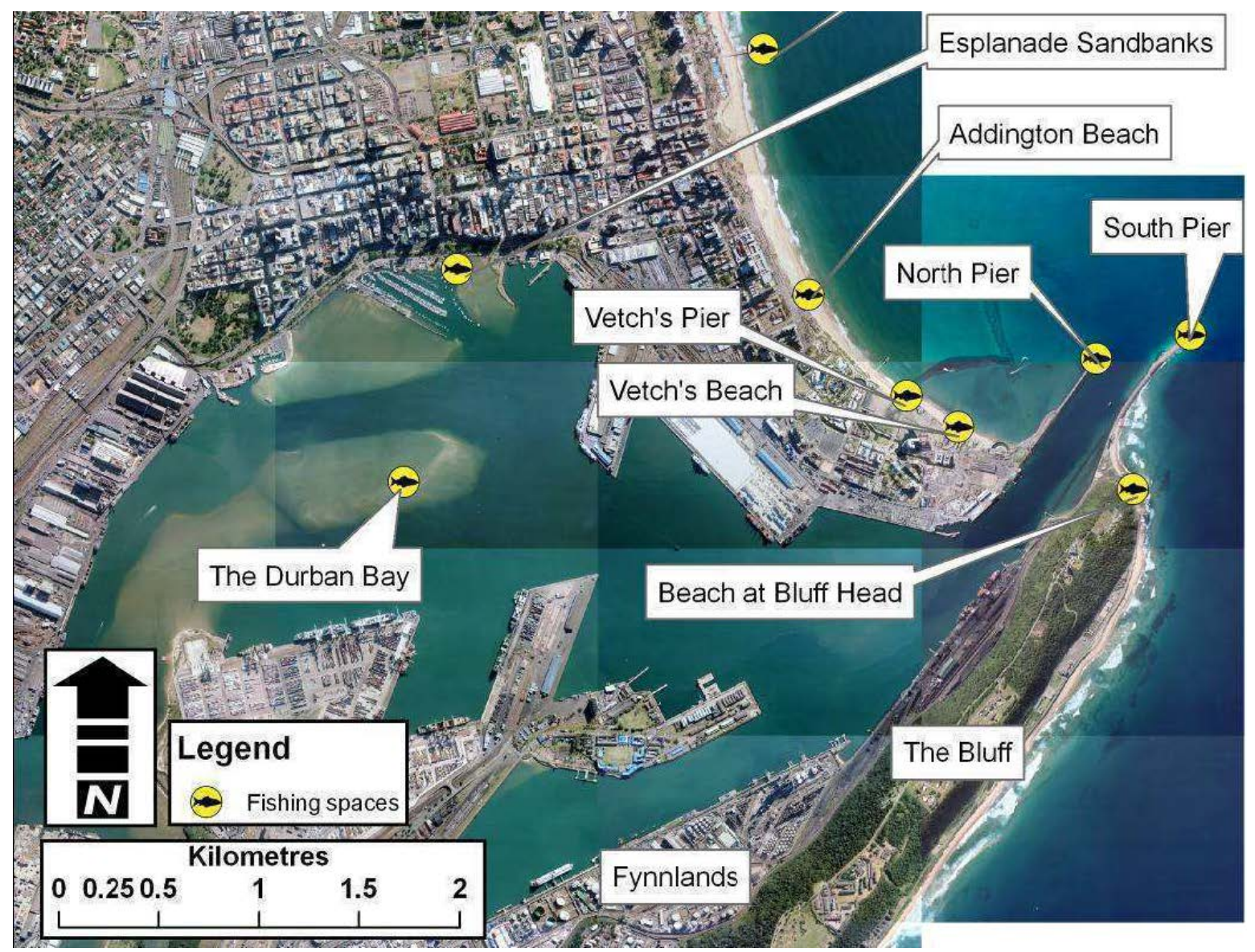

Figure 2: Aerial photograph showing popular fishing locations in and around Durban's harbor (Dray 2009)

Another spot with access to the dredged shipping channel and its deep waters are the Esplanade sandbanks at the north end of the harbor (Figure 2). Here fisherman wade out at low tide to cast near the channel with rod and reel. In addition, at extreme low tides when the sand banks are exposed, there are groups of 
fishermen who 'pump' cracker shrimp, also known as mud prawns, from the sand in order to sell them as bait (Dray 2009). These grounds are close to popular tourist and nightlife spots along the Esplanade, however mud prawns and cracker shrimp fisherman are often subjected to search, seizure, and arrest by patrolling police officers as the collection of these marine species for sale as bait is not legal (Dray 2009). A final popular fishing spot is Grunter Gully, located at the southern end of the harbor, within the mangrove forests of the port's backwaters. Named for the eponymous fish species that is most commonly caught there, many fishers remember the location fondly as a productive fishing spot that is also family friendly:

Grunter Gully is a spot where you can go and relax, bring your kids, and everyone can have a good time... Plus you catch a lot of Grunters! Big fish there. (Mohammed, 04/05/2018)

However, this area has progressively deteriorated due to industrialization and water pollution, and some fishers are reluctant to eat the fish that come out of the water there (Ahamed, 05/05/2018). Nonetheless, easy access to public roads and the reliability of catches have kept it as a desirable fishing spot for both recreational and subsistence fishers (D'Sa, 07/05/2018).

\section{Closure and resistance}

In the aftermath of the September $11^{\text {th }}$ terrorist attacks, American border control agencies began to focus their attention on points in the global transportation system prior to U.S. borders. Among these points is every major seaport that ships containers to the U.S., including, of course, Durban. As early as 1997, American assessments of border control in South Africa identified vulnerability in the security of Durban's harbor. Steinberg describes one analysis:

...there appeared to be little or no control over gaining access to the port inspections area. The general public has access to cargo areas, vessels and warehouses. The security personnel assigned to control access appeared ill-trained to maintain the high security level that is necessary for control and deterrence. The lack of physical barriers, signage and lighting compound the challenge. (Steinberg 2005: 9)

From 2002 the U.S. began exerting its considerable economic and political muscle to reshape the international maritime environment. As a senior official within Durban's harbor described:

Since $9 / 11$, the entire emphasis has shifted to the security of the global trade chain. If the U.S. feels secure, the whole world should feel secure. If the U.S. feels threatened, the whole world must both feel threatened and behave as such. The U.S. has extended its borders; the first line of defence extends as far as Durban. (Steinberg 2005: 9)

The post-9/11 maritime environment ushered in dramatic changes to the nature of physical security and border control at Durban Harbor. In December 2002, signatories to the International Convention for Safety of Life at Sea (SOLAS) signed an International Ship and Port Security Code (ISPS), under the auspices of the International Maritime Organisation (IMO). The code consists of a series of measures to strengthen security at ports, on vessels and in international waters (Steinberg 2005). To this end it allocates responsibility to a host of role players from shipping lines to port operators to securitize their operations, with the TNPA overseeing a program to progressively cordon off the harbor from the surrounding city, restricting access to the general public (Steinberg 2005). However, messaging from the TNPA around these measures has down-played security concerns and emphasized the importance of international compliance as an essential measure for ensuring Durban's competitiveness as a world-class port (Dray 2009). This reflects the growing concern of the TNPA over the future obsolescence of Durban's port in the face of increased competition from new port projects along the east African coast (Bond 2019). 
Implications of these decisions for subsistence fishers were immediate and dire. In early 2003 the TNPA publicly proclaimed that fishers would no longer be able to access the sandbanks off the Esplanade. The TNPA announcement explained that individuals wading out (or walking at low tide) to fish from the banks posed a security threat to the ships passing through the nearby channel to Maydon Wharf (D'Sa, 07/05/2018). Later that same year, the Passenger Rail Agency of South Africa (PRASA), the state-owned-enterprise that operates the Metrorail, a commuter light-rail service, announced their intention to suspend service to West's Station (see Figure 1), the terminus of the line running into the harbor, and the principal access point for fishers accessing South Pier. In this instance PRASA did not provide an explanation, however Desmond D'Sa (07/05/2018), the chairman of the South Durban Community Environmental Alliance (SDCEA), interprets the move as a clear effort to bar access to South Pier. The decisions, coming in quick succession, provoked an outcry within the fishing community. The closure of West's Station in particular, triggered the loudest response, as with West's closure fishers would be forced to walk an extra four kilometers through broken and industrialized terrain to reach the pier or to return home with their catch, effectively barring access to 'the Poor Man's Boat' for large numbers of elderly fishers who would not be able to manage the distance (Mohammed, 04/05/2018).

Outrage however, quickly turned to organization, and a group of active South Pier fishers approached the South Durban Community Environmental Alliance (SDCEA), an environmental justice organization active within the south Durban industrial basin, for legal advice. SDCEA was able to arrange a venue at City Hall for a community meeting, however a strong showing from fishers, including a petition with nearly 2,000 signatures, failed to draw the attention of local politicians. Discouraged by the failure at City Hall, SDCEA arranged a march to the central train station in town. On November $24^{\text {th }}$, 2004 hundreds of fishers occupied the station over the course of the day, forcing a conversation with the TNPA and Metrorail which eventually resulted in the resumption of services to West's Station (D'Sa, 07/05/2018). As Mohammed (04/05/2018) explained, the battle for West's Station impressed upon the fishing community the importance of organization in the face of an increasingly exclusionary municipality and port management. As a result, the KwaZulu-Natal Subsistence Fishers Forum (KZNSFF) was formed in late 2004 with the assistance and sponsorship of SDCEA (Dray 2009). The purpose of the forum is to provide the fishers with a unified front and platform when negotiating with the state over shared interests, or as D'Sa (11/12/2006) describes, "to have a collective voice to raise their voices against all the injustices, against all their spaces being blocked off, against the only thing they got left, that keeps them sane, that keeps them going."

The KZNSFF was quickly put to the test. In 2005, the TNPA announced their intention to close both North Pier and South Pier for extensive renovations; both piers would be substantially reworked, while North Pier would be moved 100 meters to the north to accommodate a wider channel into the harbor (Dray 2009). The KZNSFF quickly recognized the impact that any changes to the piers would have on their community and were resistant to any changes. During the environmental impact assessment (EIA) process the KZNSFF organized fishers to attend public meetings, while SDCEA was also active in the consultative process. As D'Sa (07/05/2018) recalls, both groups tried hard to stop the process, but were ultimately ignored. Mohammed (04/05/2008) remembers during consultations the TNPA declaring that the closures would only be temporary, were for the safety of the fishers, and that they would be able to return to the piers in a year's time after construction had finished. He notes that many fishers accepted the proposal, which weakened resistance, while SDCEA declined to bring legal action to delay the project (Mohammed, 04/05/2008).

In early 2006 the TNPA began the renovation of South Pier, the widening of the harbor channel, and the construction of the new North Pier. By mid-2007 construction had finished but the piers remained closed to the public (D'Sa, 07/05/2018). In response the KZNSFF mobilized a number of protest measures. The first occurred on May 29th, 2007 at the Durban Yacht Club, where busloads of fishers from south Durban gathered to march to the TNPA offices in order to hand over a memorandum on the continued closure of the piers (DYC, 29/05/2007). During their march fishers carried posters with slogans such as "Fishing is our living", "We are unemployed", "Government only cares for rich people" and "South Pier is our only home to fish" (DYC, 29/05/2007). Some of the fishers were heard shouting "West side till we die" referring to the 2004 battle to reopen West's Station. Two weeks later, on the 15th of June, after the TNPA had failed to respond to the KZNSFF's memoranda, the KZNSFF organized an overnight occupation of South Pier. During the occupation fishers brought their families and spent the night fishing together in solidarity (Mohammed, 04/05/2018). The 
occupation was followed in September by the protest mentioned in the introduction to this article. The protest was held on the 26th outside Durban's International Conference Centre (ICC) where the current CEO of Transnet was attending a conference. The protesters included fishers and residents from the Fynnlands area who recently experienced the effects of an explosion on the 18th of September at the Island View storage facility (see Figure 1) (Sapa, 18/09/07). The explosion resulted in the death of one person and potentially harmful chemicals being inhaled by residents from the fumes of the explosion (de Boer and Mhlongo, 19/09/07; Gerretsen, 21/09/07). However, at this time, the Transnet CEO declined to speak to protestors or accept their memorandum (D'Sa, 07/05/2018).

This campaign did not have a clear or immediate impact on accessibility of the harbor, however, and the Piers remained closed to the public. Victory, in the end, came not only from protest action, but also through a coordinated legal campaign. In 2009 the KZNSFF took the matter of exclusion to the Ports Regulator of South Africa, arguing that the restrictions infringed on the subsistence fisher's right to food and freedom (Dray 2009). At the same time, Grunter Gully was closed by the TNPA, citing safety and security issues, however, as D'Sa (07/05/2018) notes, the decision immediately followed the filing of KZNSFF's case against the TNPA. The breakthrough came in 2011 when the Ports Regulator ruled that the subsistence fishermen should be recognized as port users, however they did not make any ruling on the merits of the subsistence fishermen's contentions relative to where fishing should take place (Ports Regulator 2012). D'Sa (07/05/2018) describes this verdict as a major turning point for the KZNSFF, as it allowed them to contest their right to access from a position of equality with the TNPA. Shortly after the decision was published the KZNSFF was able to use this as leverage to renegotiate the reopening of the Esplanade sandbanks, however the TNPA continued to delay regarding the piers. On October 21 $1^{\text {st }}, 2012$ the KZNSFF once again invaded South Pier, only to be dislodged by police and private security guards working under order from the TNPA (Maharaj 2017). Finally, in early 2013 an exasperated KZNSFF organized the occupation of Bayhead Road, the main artery into the container port, blocking traffic for four hours into the port (Ahamad, 05/05/2009). The blockade forced the then Minister of Public Enterprise, Malusi Gigaba, to urgently direct the TNPA to allow access to subsistence fishers and to expedite an agreement on the re-opening of the piers. The decision led to an agreement in principle that all former public spaces should be open to subsistence fishers, and in August 2013 South Pier was officially reopened (D'Sa, 07/05/2018).

\section{6. "They treat me like I'm a terrorist because I'm poor": criminalizing poverty}

To date, both Grunter Gully and North Pier remained closed. Furthermore, although South Pier has been re-opened, fishers maintain that both the quality and quantity of their catches has been negatively affected by the renovations to the pier and the shifting of the channel closer to North Pier. Though the KZNSFF has had notable successes in asserting the right of its members to practice their livelihood, their struggle has taken nearly 15 years and consumed immense amounts of time and resources to fight. As D'Sa (07/05/2018) described, the 2011 decision by the Ports Regulator that the subsistence fisherman should be recognized as port users represented a turning point in the struggle for the harbor, as it allowed the KZNSFF to negotiate with the TNPA over access and security issues from a position of equality. Since, D'Sa (07/05/2018) has reported that the TNPA has been reconciled to reaching some sort of settlement with fishers that would accommodate their needs, while safeguarding the port facilities. Despite this shift, there remains a strong perception within the subsistence fishing community that their exclusion occurred, not because of a need to bring the port area up to new international security standards, but because they are poor (D'Sa, 07/05/2018). One fisher standing on South Pier described this skepticism towards the TNPA, "they treat me like I'm a terrorist because I am poor. Transnet thinks I'm a threat to all of the huge ships that come through this channel? What can I do? This is a fishing pole not a bazooka" (Nigel, 07/05/2018).

This reflects the lack of communication between Transnet and fishers around port issues, however a number of other observations have contributed to the perception amongst fishers that their exclusion has been due to how they are rather than to security concerns. First, in 2003, when the TNPA closed the Esplanade sandbanks to fishers, they significantly altered the way the public could access the area. They did this by introducing a permit system, by which only registered individuals would be allowed into designated port areas 
- including the sand banks and the adjoining shoreline (Dray 2009). However, access permits would not be needed to access adjacent up-scale venues frequented by tourists and the wealthy, including two private yacht clubs. Places deemed to be 'recreational' or 'general public access' would not be gated, but traditional fishing spaces, used by both subsistence and recreational fishers for generations, were not included in this definition (Dray 2009).

Similarly, at North Pier, fishers reported that, despite its closure, private water sports clubs at Vetch's Beach (see Figure 2), had maintained unbroken and free access to the pier to launch boats, dive, or even fish (Yeshelen, 05/05/2018). Furthermore, one fisher speculated that the re-opening of 'Lucky Dip' was being delayed, because the fishers did not meet the socio-economic vision that planners and elite private club members have for the area (see Figure 1) (Abdul, 05/05/2018). The TNPA has been content to draw out the re-opening of the pier, citing issues such as a lack of public toilets as reason for delay (D'Sa 07/05/2018). However Maharaj (2017) accredits the continued closure of the pier to long-standing plans to construct a private yacht marina and hotel development in the adjacent Point and Vetch's beach areas. Meanwhile, recreational boat users in Durban's harbor have been unaffected by 'no trespassing' signs placed by port authorities (Maharaj 2017). Thus, although fishers were initially excluded for security and safety concerns, their continued exclusion has been maintained in order to benefit private interests. These marginalized groups are not given the 'right to the city' and are treated like sub-citizens due to their economic standing, while public space is appropriated to make way for development and restaurants, high society clubs and bars; exclusive spaces (Mitchell \& Staeheli 2006). These elements benefit from securitization, as they clear public space of 'undesirable elements', allowing elites exclusive use (Becker and Müller 2013; Belina and Helms 2003; Bodnar 2015; Wacquant 2008).

This dynamic of dispossessing the poor to benefit the rich also seems to be present regarding access to marine resources. We have seen the impacts the enclosure of Durban's harbor has had on the ability for subsistence fishers to practice fishing to support their livelihoods. Yet, commercial fishers (and wealthy recreational fishers) have not been affected in the same way. Because they are better resourced, owning boats that are able to travel out to sea, Durban's commercial fishers do not rely on public space in the same way that subsistence fishers do, so their work has not been disrupted by events in the harbor (Mohammed, 04/05/2018). Indeed, there is a perception among some subsistence fishers that their exclusion has been to the benefit of commercial fishers who, in their absence, have enjoyed better catches and had more exclusive control over Durban's fresh fish market (Abdul, 05/05/2018). Furthermore, although South Africa has restricted the rights of their own citizens to fish for their subsistence, international fishing trawlers remain a constant fixture in South African waters (D'Sa, 07/05/2018). For example, in 2014 SDCEA wrote to the Ministry of Agriculture, Forestry and Fisheries and the Ministry of Water Affairs expressing outrage over the South African government's move to grant permission to an additional ten foreign vessels to fish in South African waters (Maharaj 2017). The presence of these ships exposes the 'double-standards' being exercised towards governing access to South Africa's marine resources (Maharaj 2017). During one visit to South Pier a fisher gestured out to a vessel barely visible on the horizon and observed the irony of his situation, saying:

They are able to fish, but I am treated like a criminal for trying to eat, for trying to feed my family. How many fish do they catch every day? A hundred? A thousand? I just want something for the pot. Who's the criminal? (Abdul, 18/05/2018)

As a result of securitization, subsistence fisherman have been criminalized for being poor, while foreign interests and the wealthy are able to comfortably enjoy exclusive access to maritime economic opportunities.

Finally, it must be noted that in South Africa race and class are often intrinsically linked and are often central to how a narrative of exclusions actively plays out. For example, we have already described how the legacy of apartheid has shaped both the location and methods used by subsistence fishers today. However, despite the arrival of democracy in 1994, the commercial fishing industry in Durban remains predominantly white. Furthermore, the membership of the private clubs on the Esplanade and at Vetch's beach are also predominantly white, while tourism and entertainment developments in the Point are predominantly driven by wealthy white, or foreign, investors (D'Sa, 07/05/2018). This has contributed to a situation in which the burden 
of securitization is being disproportionately felt by non-white subsistence fishers, to the benefit of a white, elite minority.

\section{7. "How are we gonna survive?": coping with exclusion}

How do Durban's subsistence fishers interpret and experience their exclusion from the harbor? At an institutional level the KZNSFF has been active in opposing the closure of fishing spaces and fighting for the rights of the subsistence fishers, however protests and petitions take time, and fishers need to provide for their families in the interim. In response, fishers have devised a number of micro-level strategies, Scott's (1985) 'weapons of the weak', in order to survive.

First, many defy official efforts to enclose the harbor and continue to fish in prohibited spaces. One fisher described how he regularly hides in between pylons on North Pier in order to be out of sight from port security (Abdul 05/05/2018). However, this has had consequences, and in 2016 he, along with 5 other fishers, were arrested on North Pier for trespassing (Abdul, 05/05/2018). With the assistance of the KZNSFF's legal counsel these charges were ultimately dropped (D'Sa, 07/05/2018). Another popular way of avoiding port security is fishing at night or fishing in mass groups, with the hope that the darkness or their sheer numbers will protect them from arrest (Dray 2009). Finally, some have resorted to bribing security guards for access or to be left alone. As one fisherman described, "for 100 Rand you can fish anywhere you would like" (Ahamed, 05/05/2018). This, expense, however, is beyond the reach of most subsistence fisherman and the practice is condemned by the KZNSFF (KZNSFF Meeting, 17/01/2018). Another fisher reported an increased law enforcement presence along the north bank of the harbor and described being harassed by police on a number of occasions (Vishnu, 05/05/2007). He described how he has to take risks, including taking chances with his personal safety, in order to catch mud prawns, and that if the police caught him he could be fined or even jailed (Vishnu, 05/05/2007).

Ultimately, however, the closure of the harbor areas has effectively pushed out the majority of subsistence fishers (KZNSFF Meeting, 17/01/2018). As a result, many fishers have had to abandon their old fishing spots and move to other fishing spaces that are already occupied by others. This contributes to overcrowding on public piers and overfishing which often leads to animosity amongst the fishers. As one fisher who had been forced to move to the beachfront described: "some people do come and over fish, they come with a couple rods and they exclude others" (Logan, 05/04/2007). Furthermore, this overcrowding has also led to conflict between recreational and subsistence fishers, the latter resenting the often better-resourced hobbyists (Abdul, 05/05/2018).

These dislocations have had other, very real consequences for livelihoods, as there is a general consensus that the new spots are not as nearly as productive as the spaces in the harbor. As one elderly fisher explains:

Back when North Pier was open and before South Pier was renovated, you never came home empty handed. You were always guaranteed to catch a fish. And big fish at that! Now, you never know. The beachfront, is unpredictable, and you don't catch get the variety of catch that we got from the piers. I can no longer make a living fishing anymore. I have to find other ways to make money, now I just fish to put something in the pot at home. (Mohammed, 04/05/2018)

Furthermore, many of these newly claimed fishing spots are further away, and often outside of the city. These locations are difficult to reach and are not well serviced by public transportation, which excludes many of the poorest fishers (Abdul, 05/05/2018). As a result, many fishers, particularly the most vulnerable, struggle to survive. Most of the subsistence fishers depend on fishing to survive, and fishing forms a significant part of their livelihoods. Although some fishers have jobs, fishing helps them to supplement their incomes and also provides an income for those who are out of work. Those most vulnerable are the fishers who depend solely on fishing and have no alternative sources of income. As one fisher who relies only on fishing stated, "my main concern is survival. How are we gonna survive? There are no jobs for us. How we gonna survive?" (Hashim, 15/06/2007). 


\section{History, memory, and loss}

The closure of the harbor has had other, less tangible impacts on subsistence fishers, disconnecting them from a lifestyle and culture that has been central to their community for generations. As Zukin describes, "Public spaces are the primary site of public culture; they are a window into the city's soul" (Zukin 1995: 259). The fishing spaces of Durban are part of the culture of the city. As such, there is a general feeling among fishers that if their access to the public fishing spaces is lost, their heritage, which has developed over the last century, would be under threat, and could possibly be destroyed (Dray 2009). Knowledge about the tides, wind, seasons and different bait types has developed and transmitted over generations and may be lost forever. If more public spaces are closed off to the fishers, the culture of the fishers of Durban will not have a physical space to be displayed and thus could be lost. The fishers feel a deep sense of loss when asked about the closure of spots such as the South Pier, and feel that their heritage will be destroyed (Dray 2009).

At a protest against the closure of the South Pier, Ashwin Desai, a popular south Durban activist, commented on the fact that fishing has been in these families for generations and that it is their right to be able to fish in the harbor as their forefathers did and this must not be taken away from them (Desai, 29/05/2007). Addressing the TNPA, he shouted:

"You [the fishers] have fished here for over 100 years"..."they [the TNPA] must go f*** themselves"... "they are creating unemployment" ..."it is our right to fish." (Desai, 29/05/2007)

Unfortunately, though, many fishers have failed to develop alternatives in the face of the closure of the harbor, and many have developed a sense of hopelessness towards their current situation. This hopelessness was particularly acute during the mid-2000s, prior to the successful 2011 ruling by the Ports Regulator and the protest action which culminated in the reopening of South Pier in 2013. Some of the fishers had a general apathy toward doing anything practical and although some had heard of the KZNSFF and were informed about meetings and protests that were being held, they did not participate. As the SDCEA Chairperson explained, "my brother is a fisherman, he's got an angry streak. He gets angry with the fishermen...he wants the fishermen to participate, [and] gets angry with them who don't want to participate" (D'Sa, 11/12/2006). But it is difficult to get a group like the fishers to get motivated and involved especially since most of them rely on fishing and find it difficult to take time off to go to meetings and protests as it takes time away from their fishing. As a KZNSFF representative stated "the reason why many fishermen don't have a voice is because they rely on it [fishing] and they can't come to meetings, 'cause if they away from their workplace nobody's gonna pay them, or compensate them" (Mohammed, 03/04/2007). Other fishers displayed feelings of hopelessness and felt their efforts were futile against the parastatal TNPA who they are fighting against (Dray 2009). As one fisher who had moved to the beachfront stated, "There is nothing I can do, nothing..." (Venolan, 3/07/2007). And another older fisher also felt powerless to affect the situation, "no...nothing... I have to just battle on a pension..." (Mason, 11/08/2007). The reopening of South Pier in 2013 was a dramatic success and invigorated the membership of the KZNSFF (Mohammed, 04/05/2018). However, since this milestone, momentum has stalled over continued delays regarding the reopening of North Pier and Grunter Gully and the threat of future protest action (D'Sa, 07/05/2018).

\section{Concluding remarks}

The purpose of this article has been to unpack the securitization narrative in order to examine how exclusion through securitization occurs in practice, through the everyday experiences of Durban's subsistence fishers. So how does securitization contribute to exclusion? By enclosing public space under the guise of safety and security; through the construction of fences, boom-gates, and barriers; by levying fines and arresting offenders; by employing police and private security to enforce exclusion and to protect corporate interests, and finally, by criminalizing a livelihood and community that has existed for generations (Dray 2009; Maharaj 2017; Pillay 2002; Scott 1994). Securitization has excluded Durban's subsistence fishers from public space by allowing the continued neoliberal dispossession and displacement of the poor, in favor of elites and capitalist schemes for accumulation (Harvey 2008; Maharaj 2017). 
How has this exclusion affected fishers' ability to participate in South Africa's blue economy? As we have shown, fisher's livelihoods are deeply connected to traditional fishing spots and cannot be easily transferred to other locations. As a result, any dislocation can have significant consequences, in terms of income and food, for the lives of these individuals and their families. The securitization of Durban's harbor, by denying access to subsistence fishers, has taken an immense toll on the livelihoods of entire communities, while jeopardizing a culture that has developed over 150 years. Furthermore, this exclusion has not been felt by a wealthy, predominantly white, minority of commercial fishers, investors, and tourists who have been able to adapt to enclosure, or who have been excluded from new regulations. Nonetheless, the success of the KZNSFF in articulating and asserting the rights of its members to public space stands as a successful model of mobilization and resistance in the face of securitization and neoliberal exclusion. As this study clearly demonstrates, securitization should be looked at critically, if all citizens are meant to share equitable access to public space and the blue economy.

\section{References}

Attoh, K. 2011. What kind of right is the right to the city? Progress in Human Geography 35: 669-685.

Baillache, E. 2017. Dig-out port a 'no go' until 2030. South Coast Sun, February 17, 2017. [accessed April 11 2018]. http://southcoastsun.co.za/90710/dig-out-port-a-no-go-until-2030

Becker A. and M.M. Müller. 2012. The securitization of urban space the "rescue" of downtown Mexico City. Latin American Perspectives 40(2): 77-94.

Belina, B. and G. Helms. 2003. Zero tolerance for the industrial past and other threats: policing and urban entrepreneurialism in Britain and Germany. Urban Studies 40: 1845-1867.

Bodnar, J. 2015. Reclaiming public space. Urban Studies. 52(12): 2090-2104.

Bond, P. 2019. Blue economy threats, contradictions, and resistances seen from South Africa. Journal of Political Ecology 26: 341-362.

Bond, P. and A. Desai. 2011. Prefigurative political ecology and socio-environmental injustice in central Durban. Capitalism Nature Socialism 22(4): 18-42.

Bueger, C. 2013. Communities of security practice at work? The emerging African maritime security regime. African Security 6(3-4): 297-316.

Caldeira, T.P.R. 2001. City of walls: crime, segregation and citizenship in São Paulo. Berkeley: University of California Press.

Childs, J. and C.C. Hicks. 2019. Securing the blue: political ecologies of the blue economy in Africa. Journal of Political Ecology 26: 323-340.

Cornelissen, S. 2011. Mega event securitization in a third world setting: glocal processes and ramifications during the 2010 FIFA World Cup. Urban Studies 48(15): 3221-3240.

Cruisemapper. 2018. Durban (South Africa). Sliven, Bulgaria: VT Explorer. [accessed March 29 2018] http://www.cruisemapper.com/ports/durban-port-90

De Boer, H. and M. Madlala. 2008. Durban Port security breach. IOL News, October 1, 2008. [accessed August 18 2018]. https://www.iol.co.za/news/south-africa/durban-port-security-breach-418448

Dray, A. 2009. The politics of the privatisation of public space: the subsistence fishers of Durban, KwaZuluNatal. M.S.S. dissertation. Durban, South Africa: University of KwaZulu-Natal.

Dyer, J. 2014. The consequences of Durban's proposed port development. UKZN Centre for Civil Society Presentation Seminar. May 2014. [accessed March 29 2018] http://ccs.ukzn.ac.za/files/CONSEQUENCES\%20OF-DURBAN\%E2\%80\%99S\%20PROPOSED-PORT-\%20DEVELOPMENT.pdf

Foley, R. 2017. 'One blue'. Dialogues in Human Geography 7(1): 32-36.

Freedman, S. 2013. History of Durban Harbor from 1842. Durban: Stuart Freedman.

Freund, B. and V. Padayachee (eds.). 2002. (D)urban vortex: South African city in transition. Pietermaritzburg: University of Natal Press. 
Habib, A and V. Padayachee. 2000. Economic policy and power relations in South Africa's transition to democracy. World Development 28(2): 245-263.

Hansen, K.T. and M. Vaa (eds.). 2004. Reconsidering informality: perspectives from urban Africa. Uppsala: Nordiska Afrikainstitutet.

Harvey, D. 2000. Spaces of hope. Berkeley: University of California Press.

Harvey, D. 2008. The right to the city. New Left Review 53: 23-40.

Iveson, K. 2007. Publics and the city. Oxford: Blackwell.

Jones, T. 2002. The port of Durban, lynchpin of the local economy? In Freund, B. and V. Padayachee (eds.). (D)urban vortex, South African city in transition. Pietermaritzburg: University of Natal Press. Pp. 69106.

Landman, K. 2012. Reconsidering crime and urban fortification in South Africa. In V. Cecatto (ed.). Urban fabric of crime and fear. London: Springer. Pp. 239-264.

Leitner, H., J. Peck and E.S. Sheppard (eds.). 2007. Contesting neoliberalism- urban frontiers. New York: Guilford.

Lemanski, C. 2004. A new apartheid? The spatial implications of fear of crime in Cape Town, South Africa. Environment and Urbanization 16(2): 101-112.

Low, S.M. and N. Smith (eds.). 2006. The politics of public space. London: Routledge.

MacLeod, G. 2011. Growth machine to post-democratic city? Urban Studies 48(12): 2629-2660.

Maharaj, B. 2017. Contesting displacement and the struggle for survival: the case of subsistence fisher folk in Durban, South Africa. Local Economy 32(7): 744-762.

Mara, J. 1986. A fisherman's tale, fifty years of angling along the Natal Coast. Unpublished.

Marie, S. 1986. Divide and profit: Indian workers in Natal, Durban. Worker Resistance and Culture Publications. University of Natal-Durban.

Meyer, J. 2007. Harbor may become no-go zone for public if new rules apply. Sunday Tribune, November 4.

Mitchell, D. and L. Staeheli. 2006. Clean and safe? Property redevelopment, public space, and homelessness in downtown San Diego. In Low, S.M. and N. Smith. (eds.). The politics of public space. New York: Routledge. Pp. 143-175.

Morrissey, K. 2017. It's not just a blue economy moment... Dialogues in Human Geography 7(1): 42-44.

Mottier. V. 2005. The interpretive turn: history, memory and storage in qualitative research. Forum: Social Research 2(33).

Peck, J. 2004. Geography and public policy: constructions of neoliberalism. Progress in Human Geography 28(3): 392-405.

Pillay, G. (ed.). 2002. Come to the Point: the history of the Indian Community and some well-known personalities. Durban, South Africa: Point Indian Remembrance Committee.

Poe. M.R., P.S. Levin and N. Tolimieri. 2015. Subsistence fishing in a $21^{\text {st }}$ century capitalist society: from commodity to gift. Ecological Economics 116: 241-250.

Ports Regulator. 2012. An appeal before the Ports Regulator against a decision of the authority. Reference number: 2009/08/0001.

RSA. 1998. Marine Living Resources Act No. 18 of 1998. Cape Town: Government Gazette.

RSA. 2005. National Ports Act. Cape Town: Government Gazette.

RSA. 2009. Repeal of the Harbor Regulations. Cape Town: Government Gazette.

Scott, D. 1994. Communal space construction: the rise and fall of Clairwood and District. Ph.D dissertation. Durban, South Africa: University of Natal.

Scott, D. and C. Criticos. 1988. Hanging up the nets: the history of the Durban Bay fishing community. Durban: University of Natal.

Scott, J.C. 1985. Weapons of the weak. New Haven: Yale University Press.

Smith, N. 1996. The new urban frontier: gentrification and the revanchist city. London: Routledge. 
Skinner, C. 2008. Street trade in Africa: a review. Wiego Working Paper No 5. [accessed March 22 2018] http:// wiego.org/sites/wiego.org/files/publications/files/Skinner_WIEGO_WP5.pdf.

Soja. E. 2000. Postmetropolis: critical studies of cities and regions. New York: Blackwell.

Steinberg, J. 2005. Drug smuggling and border control at Johannesburg International Airport and Durban Harbour. Paper 104. Institute for Security Studies.

Urquhart J. and T. Scott. 2013. Constructing 'the Stade': fishers' and non-fishers' identity and place attachment in Hastings, south-east England. Marine Policy 37(1): 45-54.

Van Groothest, S. 2011. Resistance and representation: the organization of protest by subsistence and recreational fisherman during the FIFA World Cup 2010. M.A. dissertation. Durban, South Africa: University of KwaZulu-Natal.

Veuthey S. and J. Gerber. 2011. Accumulation by dispossession in coastal Ecuador: shrimp farming, local resistance and the gender structure of mobilizations. Global Environmental Change 22: 611-622.

Wacquant, L. 2008. Urban outcasts: a comparative sociology of advanced marginality. Cambridge: Polity.

Weber, R. 2002. Extracting value from the city: neoliberalism and urban redevelopment. Antipode 34: 519-540.

Winder, G.M. and R. Le Heron. 2017. Assembling a Blue Economy moment? Geographic engagement with globalizing biological-economic relations in multi-use marine environments. Dialogues in Human Geography 7(1): 3-26.

Zukin, S. 1995. The cultures of cities. Oxford: Blackwell. 